\title{
Performance of business incubators: a systematic review of evidence
}

\author{
Giovane Montine Moreira Gurgel \\ IFRN \\ Mossoró, Brazil \\ giovane.gurgel@ifrn.edu.br
}

\author{
Filipa D. Vieira, Cristina S. Rodrigues \\ Department of Production and Systems \\ University of Minho \\ Guimarães, Portugal \\ filipadv@dps.uminho.pt, crodrigues@dps.uminho.pt
}

\begin{abstract}
As a business incubator is located at the intersection of different actors (e. g. universities, governments, market), processes (e.g. entrepreneurship, innovation), micro and macro levels, investigate your performance is a great challenge for researchers. To understand what has already been done and the new paths to follow, here will be presented the state of the art of this topic in a systematic way. First, using bibliometric techniques. Second, analyzing the main contributions of the papers over the years. The results demonstrate an increase of interest in this topic, especially in the last 10 years. Using the tools of the Web of Science and some indexes (also suggesting a new one), relevant journals and routes for new research were identified. In addition to the greater presence of researchers from the United States of America (USA), Europe and Asia, it was also realized that many questions from the beginning continue today. The relationship with universities and research centers are great opportunities for further studies. Although network behavior is recognized as a relevant factor, many researches still present contradictory or ambiguous results. Delve deeper the dynamics of the incubation process, at each level of analysis, seems to be a more effective strategy for the research field progress.
\end{abstract}

Keywords-performance; business incubator; review;pop-index

\section{INTRODUCTION}

According to [1], the objectives of business incubators can be grouped in: accelerating the development of high-growth or high-tech companies; improve the quality of finance, job creation rate; provide business development opportunities in the community. As the authors themselves state, the incubator concept is nebulous and multifaceted. These distinctive features hinder the account for the population of incubators in the world [2]. As the incubator is located at the intersection of different actors (e.g. universities, governments, market), processes (e.g. entrepreneurship, innovation), micro and macro levels, work in this field is vast and has no clear boundaries. Therefore, the performance of business incubators is a major challenge for researchers.

This work look for the "state of the art" of the research not only showing the contributions of authors over the years, but also offers a systematic approach to select journals and articles more relevant to the topic. This approach combines Web of Science research tools and metrics for publications. This article is organized into five sections besides the introduction. The following section explains how the tools were used and which metrics were applied (and created). Section III shows the bibliometric overview of journals, publications and authors. Section IV presents the main evidence of the theme over the years. The conclusions are summarized in the last section.

\section{RESEARCH APPROACH}

Research was conducted in the Web of Science database. The search period was from 1900 until 2017 and only papers published in journals were selected. Some authors use different terms for business incubators, then four alternative options were used in the search: "(business OR university OR company OR enterprise) AND incubat *". The use of special characters allowed to find articles on "incubation, incubatee, incubator", among other combinations.

The search in the database Web of Science Core Collection returned 2663 articles. However, many of these were from the health area (e.g. disease research - incubation periods). After deleting articles from other areas of the search result, 430 papers remained. In order to analyze only the performance articles, a filter was applied to the search result using the term "performance". With this, it was possible to obtain a total of 150 articles. The results presented in this paper are based on this subset of 150 papers. The descriptive analysis of these articles was carried out exploring the resources available in the Web of Science.

The Hirsch index (h-index) was 27, that is, the first 27 most cited articles have at least 27 citations among all 150 found. They are the articles of great visibility for the performance of business incubators. Nevertheless, articles with large numbers of citations do not necessarily belong to journals with a tradition in the area of research in question. In order to minimize this type of influence, for example, in the evaluation of journals, the "popular" index (pop-index) was proposed, combining the $h$-index and the number of citations. Using filters and other tools in the Web of Science, it was 
possible to generate the h-index of each journal as well as the number of citations of your articles (those present in the search result). This index points to the journals that are more "popular" compared to the others present in the same search result. Thus, the higher the h-index and the more cited, the more "popular" it becomes. For example, a journal A with a single article of 100 citations will not be more "popular" than journal B with 70 citations if it has a higher h-index. Complementing the evaluation, the eigenfactor of each journal was applied to the pop-index so that the final order also takes into account the journal's impact on the scientific community.

\section{BIBLIOMETRIC OVERVIEW}

Despite the wide search interval (1900 to 2017), the oldest publication in the search result was from 1992. For 12 years, only 15 articles were published. The interval between 2005 and 2017 (Fig. 1) represents 90\% of the 150 articles found. From 2005 to 2010, 44 articles were published and from 2011 to 2017,91 papers were published. Therefore, in the last seven years there was a growth of $106.81 \%$ over the period prior to 2010. It is worth noting that older articles may contain little information in the database, so complementary surveys will always be recommended.

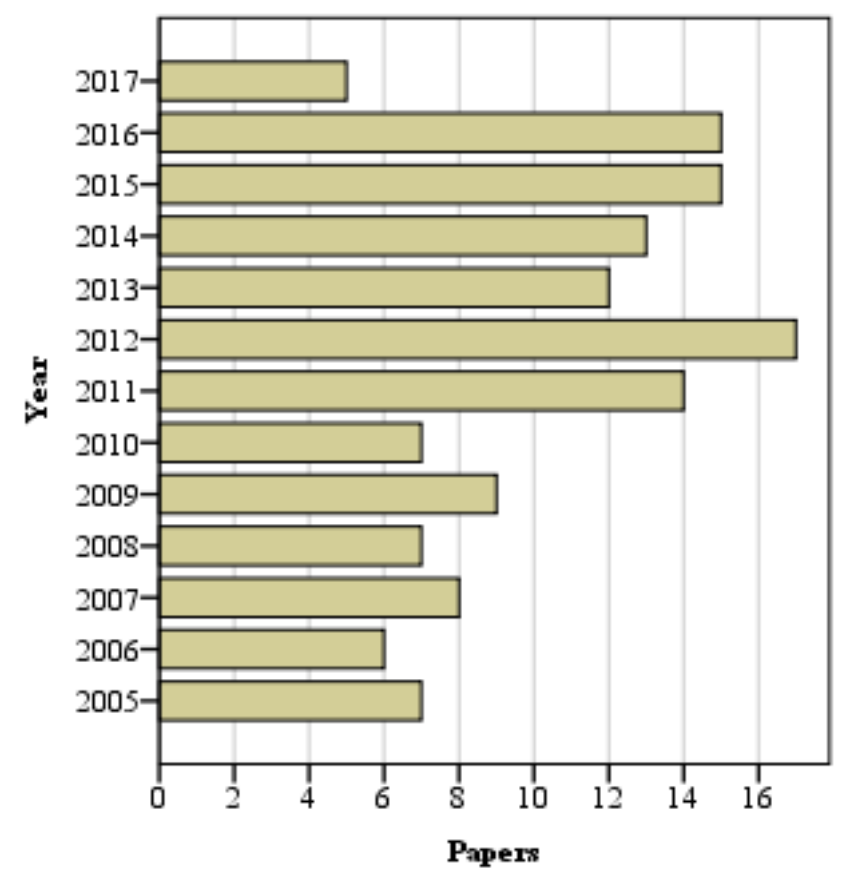

Fig. 1. Evolution of number of publications.

The evolution of citations has other pace. The first citations were registered in 1996. Until 2006 they were only 131. From 2007 to 2017 (Fig. 2) were 2545 citations, that is, $95.10 \%$ of the total citations to the 150 articles. This is not mean that the articles published since 2007 were the most cited, but this period represents an increase in interest in research on the performance of incubators. The year 2016 was the maximum point of activity on this topic: 511 citations.

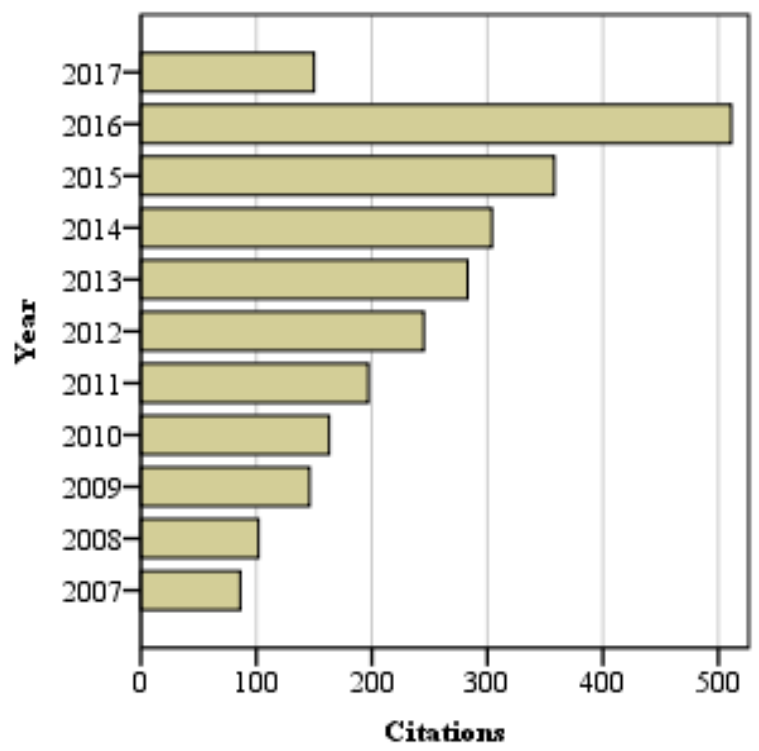

Fig. 2. Evolution of number of citations.

Analizing the search result, it was possible to identify the research areas of papers. Tab. 1 presents a comparison between the research areas and the most frequent categories according to the Web of Science. Other areas of research and categories (e.g. PLANNING DEVELOPMENT) have been identified, however, most of the papers are related to engineering, business or management research.

TABLE I. MAJOR RESEARCH AREAS AND CATEGORIES

\begin{tabular}{|c|c|c|c|}
\hline Research area & $\begin{array}{c}\text { \% of } \\
\mathbf{1 5 0}\end{array}$ & $\begin{array}{c}\text { Web of Science } \\
\text { categories }\end{array}$ & $\begin{array}{c}\text { \% of } \\
\mathbf{1 5 0}\end{array}$ \\
\hline BUSINESS ECONOMICS & 85.33 & MANAGEMENT & 59.33 \\
\hline ENGINEERING & 29.33 & BUSINESS & 36.66 \\
\hline $\begin{array}{c}\text { PUBLIC } \\
\text { ADMINISTRATION }\end{array}$ & 22.00 & $\begin{array}{c}\text { ENGINEERING } \\
\text { INDUSTRIAL }\end{array}$ & 24.00 \\
\hline
\end{tabular}

The 150 articles are distributed in 68 journals. Using the Web of Science reporting tools, the $h$-index and the total citations of each journal were obtained from the search result. With this, it was possible to calculate the pop-index. This new indicator valorize journals with a strong presence in the search result, also considering the number of citations.

Additional to this, the pop-index was multiplied by the respective eigenfactor. This operation qualifies the pop-index with information regarding the impact of each journal in the scientific community. Tab. II lists the journals sorted according to the proposed indicators. The 10 journals in this list correspond to $81.98 \%$ of the citations of all 150 papers. In fact, other metrics still pertinent, but the combination of indexes could bring valuable information. Different research fields and objectives can benefit from other combinations.

The 150 papers were produced by a total of 309 authors. Tab. III shows the regions of the authors of $91.33 \%$ of the papers. Most of the authors are from Europe, United States of America (USA) and Asia. 
TABLE II. JOURNALS RANKED BY POP-INDEX.

\begin{tabular}{|c|c|c|c|c|c|}
\hline N. & Journal & $\begin{array}{l}\text { pop- } \\
\text { index }^{a}\end{array}$ & $\begin{array}{c}\text { h- } \\
\text { index }\end{array}$ & cit. & eigenfactor \\
\hline 1 & RESEARCH POLICY & 53.97 & 7 & 467 & 0.01651 \\
\hline 2 & $\begin{array}{c}\text { JOURNAL OF BUSINESS } \\
\text { VENTURING }\end{array}$ & 21.11 & 5 & 599 & 0.00705 \\
\hline 3 & TECHNOVATION & 20.47 & 12 & 474 & 0.0036 \\
\hline 4 & $\begin{array}{c}\text { JOURNAL OF PRODUCT } \\
\text { INNOVATION } \\
\text { MANAGEMENT }\end{array}$ & 5.62 & 5 & 175 & 0.00643 \\
\hline 5 & $\begin{array}{c}\text { TECHNOLOGICAL } \\
\text { FORECASTING AND } \\
\text { SOCIAL CHANGE }\end{array}$ & 4.30 & 6 & 95 & 0.00755 \\
\hline 6 & $\begin{array}{c}\text { JOURNAL OF BUSINESS } \\
\text { RESEARCH }\end{array}$ & 3.64 & 4 & 76 & 0.01198 \\
\hline 7 & $\begin{array}{c}\text { ENTREPRENEURSHIP } \\
\text { THEORY AND } \\
\text { PRACTICE }\end{array}$ & 3.63 & 4 & 118 & 0.0077 \\
\hline 8 & $\begin{array}{l}\text { JOURNAL OF } \\
\text { TECHNOLOGY } \\
\text { TRANSFER }\end{array}$ & 1.44 & 6 & 116 & 0.00207 \\
\hline 9 & $\begin{array}{l}\text { JOURNAL OF } \\
\text { MANAGEMENT } \\
\text { STUDIES } \\
\end{array}$ & 0.42 & 1 & 34 & 0.01239 \\
\hline 10 & $\begin{array}{c}\text { SMALL BUSINESS } \\
\text { ECONOMICS }\end{array}$ & 0.37 & 2 & 40 & 0.00471 \\
\hline
\end{tabular}

TABLE III. NATIONALITY OF AUTHORS (91.33\% PAPERS)

\begin{tabular}{|c|c|c|c|}
\hline Country & Papers & Country & Papers \\
\hline USA & 43 & TAIWAN & 9 \\
\hline ENGLAND & 20 & PEOPLES R CHINA & 8 \\
\hline GERMANY & 13 & ITALY & 8 \\
\hline SWEDEN & 12 & BELGIUM & 8 \\
\hline SPAIN & 10 & NORTH IRELAND & 6 \\
\hline
\end{tabular}

The Tab. IV lists the authors with the highest number of published papers. These authors published $26.66 \%$ of the 150 papers.

TABLE IV. AUTHORS WITH HIGHEST NUMBER OF PAPERS

\begin{tabular}{|c|c|c|c|}
\hline Author & Papers & Author & Papers \\
\hline MCADAM M & 6 & ROTHAERMEL FT & 3 \\
\hline SCHWARTZ M & 5 & MATTHYSSENS P & 3 \\
\hline MCADAM R & 4 & MARVEL MR & 3 \\
\hline LOFSTEN H & 4 & MARLOW S & 3 \\
\hline WRIGHT M & 3 & LINDELOF P & 3 \\
\hline THURSBY M & 3 & VANDERSTRAETEN J & 2 \\
\hline
\end{tabular}

To obtain a snapshot of the relevant papers using this technique, the most cited 27 papers ( $h$-index) were listed and classified by the pop-index of their journals. The list was sorted using two columns: pop-index and then the total of citations. Tab. V lists 16 most relevant works according to these criteria. Although this list represents only $10.66 \%$ of the papers, it corresponds to $50.93 \%$ of the citations of all 150 papers. This list does not exclude other articles. These listings and criteria present significant paths to research about performance in business incubators. It is important for beginners in this line of research as well as for anyone interested in knowing which papers remain relevant or which journals are aligned with this field of research. From this list, it is possible to detect other papers and authors that are following this line of research today.

TABLE V. PAPERS RANKED BY POP-INDEX AND CITATIONS.

\begin{tabular}{|c|c|c|c|}
\hline N. & Paper & pop-index & cit. \\
\hline 1 & [3] & 53.97 & 152 \\
\hline 2 & [4] & 53.97 & 92 \\
\hline 3 & [5] & 53.97 & 88 \\
\hline 4 & [6] & 53.97 & 53 \\
\hline 5 & [7] & 53.97 & 44 \\
\hline 6 & [8] & 21.11 & 168 \\
\hline 7 & [9] & 21.11 & 148 \\
\hline 8 & [10] & 21.11 & 124 \\
\hline 9 & [11] & 21.11 & 108 \\
\hline 10 & [12] & 21.11 & 50 \\
\hline 11 & [13] & 20.47 & 92 \\
\hline 12 & [14] & 20.47 & 66 \\
\hline 13 & [15] & 20.47 & 61 \\
\hline 14 & [16] & 20.47 & 47 \\
\hline 15 & [17] & 20.47 & 40 \\
\hline 16 & [18] & 20.47 & 30 \\
\hline
\end{tabular}

\section{MAIN CONTRIBUTIONS}

Analyzing the publications of the journals indicated in the previous section, was found papers with low citations that deal with the performance of incubators of companies. For example, [19] already understood that financial incentives were not enough for the success of incubated companies. He also realized that for an incubation program to show good results it can take up to 10 years. Reference [20] considered that the improvement of the local economy is still present among the performance factors. He also emphasized that each incubator is different. Their research revealed as significant only the factors: location (large cities x small cities), number of jobs created and the services offered by the incubator.

The framework for University Technology Business Incubator (UTBI) was created by [10]. There was a need to evaluate the performance of incubators in different academic 
settings. According to the author, to evaluate the performance of UTBI, is necessary the support of multiple theories. His model seeks an overview of performance, does not explore the "black box" of the incubator.

The good performance of an incubator according to [21] lies in the adequacy between the offered services and the local market. Although there were adaptations to the context of each incubator, they identified a set of common practices in the incubators investigated. For example, the use of external resources and the existence of a full-time incubator coordinator have proved to be widely accepted practices. Reference [22] seeks to understand performance as a form of co-production (other examples of co-production: garbage collection and educational programs) between the incubated company and the incubator or external actors through a network.

Reference [3] compared two groups of new technologybased firms (NTBF). Incubators and parks were found to be very relevant in the region because of the numerous barriers that the new companies encountered - Italy had little progress related to technological advances. Although the study of [8] was not in the context of incubators, the authors did a parallel with the framework of [10]. They demonstrated that the relation with universities is positively related to the innovation of the companies - even so, there is no guarantee of this, the company always has to evaluate the risks involved.

Analyzing incubators from 40 countries, [23] identified problems in: macroeconomic conditions, business planning, inadequate sponsors, weak human resources and operational issues. In this sense, [1] understand that it is fundamental for the good performance of the incubator, the ability to adapt its practice according to the needs of the companies throughout its evolution. For [24], the incubator facilitates the entry of new technologies. In its model, the outcome is defined in terms of success (the company survives) or failure (the company is closed).

According to [9], the survival rate as a dependent variable is not a good choice for a performance model. The political issue present in other works [25], [26] is also discussed by [9] to the point of questioning whether it would not be better to evaluate how the incubator legitimizes the political interests that support it rather than verify whether it has a high success rate among incubated companies.

The relationship between knowledge and business incubation is indicated by [6] when investigating the process of spin-off generation at a research center in Belgium. Also exploring the relationship with academia, [5] examined the variables "licensing of university-created technologies" and the "participation of academics in companies". It was noticed that interaction caused a delay in the graduation of companies. Therefore, this relationship helps both consolidate companies and slows down the exit of the incubator.

The model presented by [27] detail the local context indicated by [21] as well as the antecedents and outcomes of [24]. Factors associated with incubator performance can be classified into three dimensions: internal efficiency, sustainability and impact. Reference [28] considers success factors for BITs in terms of location: population sufficient to support economic clusters and a strong university (or other research organization). Reference [29] constructed and validated a scale to measure incubator performance from the option theory and incubation model developed in a previous study [24].

Following the model of [29], [30] deepen the three dimensions using strategy theories. The value is the result of the set of services offered by the incubator as access to technology, infrastructure and networking. Reference [31] related the performance factors most representative of the incubator literature. However, just as [9] and [26], reaffirm the need for more studies that can effectively prove the relationship between different factors and incubator performance.

Reference [32] analyzed the performance of Technology Business Incubators (TBI) in Australia and Israel from the dynamics of the incubation process. The identified conflict (cultural and structural differences) between the university and the incubator has enabled incubators to cooperate more intensively in order to create new business opportunities or simply to increase knowledge, helping companies to overcome technological obstacles.

From a study in Sweden, [33] obtained a set of strategies that influence the incubator's ability to create value. The authors contribute to the research in incubators by understanding that the incubator needs a broader connection with external actors. Another study in Sweden [34] examined the impact of previous experience on the survival of incubated companies. The model also has variables related to the financial aspect and the international market.

A study by [35] in incubators in China showed that the technical and entrepreneurial supports offered by the incubator are more important than the incubator's own financial support. It was also demonstrated that the performance is related to the level of development of the city where the incubator is located. Reference [36] investigated incubator entrepreneurs in Turkey. They analyzed how the characteristics of entrepreneurs and incubators were associated with good performance. They said simple survival is not the main goal for start-ups. This was identified in the survey since incubated companies had short, medium and long-term goals, while incubator managers believed their primary purpose would be to survive.

The readiness to engage [22] got more detailed with [37]. The results showed that as companies became more developed, the less the incubator needed to act assertively in supporting the business. Despite advance in research, especially the relevance of network actions in the incubation process, [38] understand that as fragmented and lacking of better conceptualization. The authors suggest to delve deeper the topic with the help of theories, in order to avoid the contradictory and ambiguous results found in the literature.

Based on this review, it is possible to propose the following trends in incubator performance research: 
- Among the several factors found, intense local economic activity and intense scientific production seem to be contextual factors for improved incubators performance;

- Usual measures such as graduation rate or financial measures do not fully explain the performance of incubators;

- Researches began to delve deeper the incubator's "black box";

- Business maturity seems to be an important factor for incubator performance models;

- Network aspects are increasingly relevant, but there are many ambiguous or contradictory research results;

- Making clear the level of analysis is an important aspect for future research. This helps to understand the reach of the incubator's actions. It also allows comparisons and verification of causal relationships.

\section{CONCLUSIONS}

There has been a significant growth in interest in business incubator performance research - the last year was the most significant in numbers. This promotes the development of the topic and facilitates the search for journals and more relevant authors. The procedures, indexes and criteria adopted in this paper offer already consolidated paths and assist in the choice of routes for new researches. For example, the need for researchers from other countries was perceived. After all, the presence of incubators is not limited to the USA, Europe and Asia, but on all continents.

Many issues in early research continue today. Mainly the fact that performance is complex and can hardly be completely measured using only a few financial measures. It is more and more evident the need to clarify the level of analysis of the research to better understand the reach of the incubator actions. In addition to the greater regional economic activity, there seems to be consensus that an intense technological research activity is another important factor for improved incubator performance. Therefore, the relationship with universities and research centers are great opportunities for the field. Although network behavior is recognized as a relevant factor, many researches still present contradictory or ambiguous results. Delve deeper the dynamics of the incubation process, at each level of analysis, seems to be a more effective strategy for the research field progress.

\section{ACKNOWLEDGMENT}

This work has been supported by COMPETE: POCI-01-0145FEDER-007043 and FCT - Fundação para a Ciência e Tecnologia within the Project Scope: UID/CEC/00319/2013.

\section{REFERENCES}

[1] P. D. Hannon and P. Chaplin, "Are incubators good for business? Understanding incubation practice -- the challenges for policy," Environ. Plan. C Gov. Policy, vol. 21, no. 6, pp. 861-881, 2003.
[2] S. A. Mian, W. Lamine, and A. Fayolle, "Technology Business Incubation: An overview of the state of knowledge," Technovation, pp. 1-12, 2016.

[3] M. Colombo and M. Delmastro, "How effective are technology incubators?: Evidence from Italy,” Res. Policy, vol. 31, pp. 1103-1122, 2002 .

[4] F. T. Rothaermel and M. Thursby, "University-incubator firm knowledge flows: assessing their impact on incubator firm performance," Res. Policy, vol. 34, no. 3, pp. 305-320, Apr. 2005.

[5] F. T. Rothaermel and M. Thursby, "Incubator firm failure or graduation?,” Res. Policy, vol. 34, no. 7, pp. 1076-1090, Sep. 2005.

[6] N. Moray and B. Clarysse, "Institutional change and resource endowments to science-based entrepreneurial firms," Res. Policy, vol. 34, no. 7, pp. 1010-1027, Sep. 2005.

[7] R. Fini, R. Grimaldi, S. Santoni, and M. Sobrero, "Complements or substitutes? The role of universities and local context in supporting the creation of academic spin-offs," Res. Policy, vol. 40, no. 8, pp. 1113 1127, Oct. 2011.

[8] G. George, S. A. Zahra, and D. R. Wood, "The effects of businessuniversity alliances on innovative output and financial performance: a study of publicly traded biotechnology companies," J. Bus. Ventur., vol. 17, no. 6, pp. 577-609, Oct. 2002.

[9] P. H. Phan, D. S. Siegel, and M. Wright, "Science parks and incubators: observations, synthesis and future research," J. Bus. Ventur., vol. 20, no. 2, pp. 165-182, Mar. 2005.

[10] S. A. Mian, "Assessing and managing the university technology business incubator: an integrative framework," J. Bus. Ventur., vol 6568, no. 96, pp. 251-285, 1997.

[11] A. Bøllingtoft and J. P. Ulhøi, "The networked business incubatorleveraging entrepreneurial agency?," J. Bus. Ventur., vol. 20, no. 2, pp. 265-290, Mar. 2005.

[12] M. Lerner and S. Haber, "Performance factors of small tourism ventures: The interface of tourism, entrepreneurship and the environment," J. Bus. Ventur., vol. 16, no. 1, pp. 77-100, 2001.

[13] A. Bergek and C. Norrman, "Incubator best practice: A framework," Technovation, vol. 28, no. 1-2, pp. 20-28, Jan. 2008

[14] K. Aerts, P. Matthyssens, and K. Vandenbempt, "Critical role and screening practices of European business incubators," Technovation, vol. 27, no. 5, pp. 254-267, May 2007.

[15] M. McAdam and R. McAdam, "High tech start-ups in University Science Park incubators: The relationship between the start-up's lifecycle progression and use of the incubator's resources," Technovation, vol. 28, no. 5, pp. 277-290, May 2008.

[16] S. A. Mian, "US university-sponsored technology incubators: an overview of management, policies and performance," Technovation, vol. 14, no. 8, pp. 515-528, 1994.

[17] H. Kroll and I. Liefner, "Spin-off enterprises as a means of technology commercialisation in a transforming economy-Evidence from three universities in China," Technovation, vol. 28, no. 5, pp. 298-313, May 2008.

[18] M. Schwartz and C. Hornych, "Specialization as strategy for business incubators: An assessment of the Central German Multimedia Center," Technovation, vol. 28 , no. 7 , pp. 436-449, Jul. 2008

[19] G. Udell, "Are business incubators really creating new jobs by creating new business and new products," J. Prod. Innov. Manag., vol. 7, no. 2, pp. 108-122, Jun. 1990.

[20] D. Reed, "Incubator Program: Factors in a Profile of Success," J. Bus. Entrep., vol. 3, no. 1, p. 61-0_7, 1991

[21] E. Autio and M. Klofsten, "A comparative study of two European business incubators," Journal of small business management (Print), vol. 36, no. 1. pp. 30-43, 1998.

[22] M. P. Rice, "Co-production of business assistance in business incubators: an exploratory study," J. Bus. Ventur., vol. 17, no. 2, pp. 163-187, Mar. 2002.

[23] R. Lalkaka, "Business incubators in developing countries characteristics and performance Rustam Lalkaka," Int. J. Entrep. Innov. Manag., vol. 3, no. 1/2, pp. 31-55, 2003. 
[24] S. M. Hackett and D. M. Dilts, "A Real Options-Driven Theory of Business Incubation,” J. Technol. Transf., vol. 29, no. 1, pp. 41-54, Jan. 2004.

[25] B. Clarysse, M. Wright, A. Lockett, E. Van de Velde, and A. Vohora, "Spinning out new ventures: a typology of incubation strategies from European research institutions," J. Bus. Ventur., vol. 20, no. 2, pp. 183 216, Mar. 2005.

[26] S. M. Hackett and D. M. Dilts, "A Systematic Review of Business Incubation Research,” J. Technol. Transf., vol. 29, no. 1, pp. 55-82, Jan. 2004.

[27] R. Lalkaka, Technology business incubation : a toolkit on innovation in engineering, science and technology. 2006

[28] C. Tamásy, "Rethinking Technology-Oriented Business Incubators: Developing a Robust Policy Instrument for Entrepreneurship, Innovation, and Regional Development?," Growth Change, vol. 38, no. 3, pp. 460-473, Sep. 2007.

[29] S. M. Hackett and D. M. Dilts, "Inside the black box of business incubation: Study B-scale assessment, model refinement, and incubation outcomes," J. Technol. Transf., vol. 33, no. 5, pp. 439-471, Aug. 2008.

[30] J. Vanderstraeten and P. Matthyssens, "Service-based differentiation strategies for business incubators: Exploring external and internal alignment," Technovation, vol. 32, no. 12, pp. 656-670, 2012.

[31] N. Theodorakopoulos, N. K. Kakabadse, and C. McGowan, "What matters in business incubation? A literature review and a suggestion for situated theorising,” J. Small Bus. Enterp. Dev., vol. 21, no. 4, pp. 602622, 2014.

[32] T. H. Rubin, T. H. Aas, and A. Stead, "Knowledge flow in Technological Business Incubators: Evidence from Australia and Israel," Technovation, vol. 41, pp. 11-24, 2015.

[33] E. Baraldi and M. I. Havenvid, "Identifying new dimensions of business incubation: A multi-level analysis of Karolinska Institute's incubation system," Technovation, vol. 50-51, no. April-May 2016, pp. 53-68, 2016.

[34] H. Löfsten, "Organisational capabilities and the long-term survival of new technology-based firms," Eur. Bus. Rev., vol. 28, no. 3, pp. 312332, May 2016.

[35] L. Xiao and D. North, "The graduation performance of technology business incubators in China's three tier cities: the role of incubator funding, technical support, and entrepreneurial mentoring," Journal of Technology Transfer, Springer New York LLC, pp. 1-20, 31-Aug-2016.

[36] G. Guceri-Ucar and S. Koch, "Exploring business incubation practices and relationships to drivers of start-up success in Turkey," Int. J. Entrep. Innov. Manag., vol. 20, no. 1-2, pp. 1-19, 2016.

[37] M. van Weele, F. J. van Rijnsoever, and F. Nauta, "You can't always get what you want: How entrepreneur's perceived resource needs affect the incubator's assertiveness," Technovation, vol. 59, pp. 18-33, 2017.

[38] C. P. Eveleens, F. J. van Rijnsoever, and E. M. M. I. Niesten, "How network-based incubation helps start-up performance: a systematic review against the background of management theories," Journal of Technology Transfer, Springer US, pp. 1-38, 04-Oct-2016. 